\title{
Possible effects of potential lahars from Cotopaxi volcano on housing market prices
}

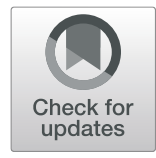

\author{
Richard Caleb Echegaray-Aveiga', Fabian Rodríguez-Espinosa ${ }^{1,2^{*}}$, Theofilos Toulkeridis ${ }^{1}$ and \\ Richard Damian Echegaray-Aveiga'
}

\begin{abstract}
The recent awakening of the Cotopaxi volcano in Ecuador set the conditions to estimate and verify the possible effects of potential lahars on residential housing unit prices. About 300,000 people live in the Los Chillos valley, which is the northern natural drainage of Cotopaxi's lahars; therefore, the effects on house values can be significant. We have used housing information from 2016 of 240 properties to settle a hedonic price model within and outside of the lahar's area. The regression model has a significant $R^{2}$ value of about 0.723 . The variable that determined the effects of potential lahar on the hedonic model demonstrates that the value of a residence house unit will increase its price by 41.99 USD for each meter away from the lahar path. Our study suggests that environmental disamenities generated by natural hazards will have a negative effect on residential house unit prices and we infer that consumers would be willing to pay a higher price in order to avoid such potential disamenities.
\end{abstract}

Keywords: Economic assessment, Floodplain, Integrated flood risk management, Risk assessment

\section{Introduction}

Hedonic housing models provide an intuitive analytical tool for adjusting property prices to environmental amenities and disamenities (Hulten 2003). The hedonic function relates to the supply and demand of different individual characteristics of properties and individual consumer taste preferences (Rosen 1974; Hulten 2003). Based on the mentioned aspects, the consumer reacts to environmental amenities and disamenities the same way as they do to the number of floors or bedrooms (Triplett 1983; Epple 1987; Feenstra 1995). Accordingly, environmental disamenities, such as contamination or natural hazards, will have a negative effect on housing attributes and prices and consumers would be willing to pay more in order to avoid such potential disamenities (MacDonald et al. 1987; Pryce et al. 2011). Bin et al. (2008) and Brookshire et al. (1985), who were the pioneers to

\footnotetext{
* Correspondence: ffrodriguez3@espe.edu.ec

'Universidad de las Fuerzas Armadas ESPE, Sangolquí, Ecuador

${ }^{2}$ Facultad de Economía, Pontificia Universidad Católica del Ecuador, Quito, Ecuador
}

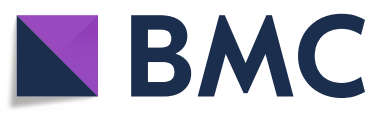

(c) The Author(s). 2020 Open Access This article is licensed under a Creative Commons Attribution 4.0 International License, which permits use, sharing, adaptation, distribution and reproduction in any medium or format, as long as you give appropriate credit to the original author(s) and the source, provide a link to the Creative Commons licence, and indicate if changes were made. The images or other third party material in this article are included in the article's Creative Commons licence, unless indicated otherwise in a credit line to the material. If material is not included in the article's Creative Commons licence and your intended use is not permitted by statutory regulation or exceeds the permitted use, you will need to obtain permission directly from the copyright holder. To view a copy of this licence, visit http://creativecommons.org/licenses/by/4.0/ The Creative Commons Public Domain Dedication waiver (http://creativecommons.org/publicdomain/zero/1.0/) applies to the data made available in this article, unless otherwise stated in a credit line to the data. consider risk factors in the context of hedonic models and housing prices, demonstrated how floods affected the coastal housing markets in North Carolina using GIS tools. Further studies of housing prices in relation and proximity to natural hazards followed (MacDonald et al. 1987, 1990; Bin and Polasky 2004; Troy and Romm 2004; Samarasinghe and Sharp 2010; Pryce et al. 2011; Egbenta et al. 2015; De Koning et al. 2016). Such studies included the analysis of the effects of flooding in communities around the USA and beyond (De Koning et al. 2016; MacDonald et al. 1990), the effects of hurricanes in coastal areas (Hallstrom and Smith 2005), the effects of erosion in rural and coastal communities (Kriesel et al. 1993; Landry et al. 2003), the effects of wildfires and forest fires (Donovan et al. 2007; Rossi 2014; Kiel and Matheson 2015) and the effects of earthquakes as well as volcanic activity (Bernknopf et al. 1990; Murdoch et al. 1993; Beron et al. 1997; Timar et al. 2014). All of these studies show that house prices decreased with increasing exposure to natural hazards. 
In the current study, we have analyzed the current economic effects of potential lahars from Ecuador's Cotopaxi volcano. This volcano, which has been categorized as being one of the most dangerous volcanoes in the world (Miller et al. 1978; Barberi et al. 1995), is located in the northern volcanic Andes and is known to have had a vast history of lahar generations due to explosions reaching a Volcanic Explosivity Index of 4-5 (Barberi et al. 1995; Aguilera et al. 2004; Aguilera and Toulkeridis 2005; Pistolesi 2008; Pistolesi et al. 2013, 2014; Toulkeridis 2013; Toulkeridis et al. 2015). Past historical eruptions have had devastating impact in the areas surrounding Cotopaxi in 1534, 1742, 1768 and 1877 , in which lahars destroyed important areas towards the northern and southern sides of the volcano and to a lesser extent towards its eastern area (La Condamine 1751; Sodiro 1877; Whymper 1892; Wolf 1878; Mothes 1992; Barberi et al. 1995; Aguilera et al. 2004; Garrison et al. 2011; Pistolesi et al. 2013, 2014). The aforementioned references describe in detail the trajectory and impact sites of the lahars as well as their volumes and velocities. Furthermore, studies of dated past lahar deposits indicate some 19 strong eruptive phases with concurrent lahar formations, suggesting a recurrence interval of $117 \pm 70$ years over the last 2200 years (Barberi et al. 1995). A lahar's travel model was developed by Padilla and Bosque (2014) based on past eruptions and lahar deposits. The model included risk vulnerabilities to assess evacuation routes and victim assistance. The Padilla and Bosque model was adopted for this study to determine critical lahar hazard areas.

Cotopaxi volcano reawakened in 2015, recording seismic unrest and hydrothermal eruptions lasting for about three months (Toulkeridis et al. 2015; Vaca et al. 2016; Toulkeridis and Zach 2017; Toulkeridis et al. 2018). Due to an unjustified alert by the underprepared volcanic monitoring staff on the 15th of August 2015, people panicked, and eight persons died due to these events (Toulkeridis et al. 2018). This resulted once again in a drop in house market prices, as house owners of buildings within the known lahar trajectory tried to sell their property and to leave this risky area. This belief is not totally unwarranted. A recent study suggest that economic losses of a potential eruption could reach 17 billion USD, while the cost estimation of mitigation structures that would prevent those potential losses was approximate 150 million USD (Rodríguez et al. 2017).

Currently, about 300 thousand people live in the Los Chillos valley, which is the northern natural drainage of Cotopaxi's lahars. Several parishes are located along Pita, El Salado, and Santa Clara rivers such as Sangolquí, San Rafael, San Pedro de Taboada, Conocoto, and Alangasí. One particular condition due to the proximity between the Pita and Santa Clara rivers (Fig. 1) is that, in the event of a volcanic eruption and the generation of farreaching lahars, flows in the Pita river will be able to

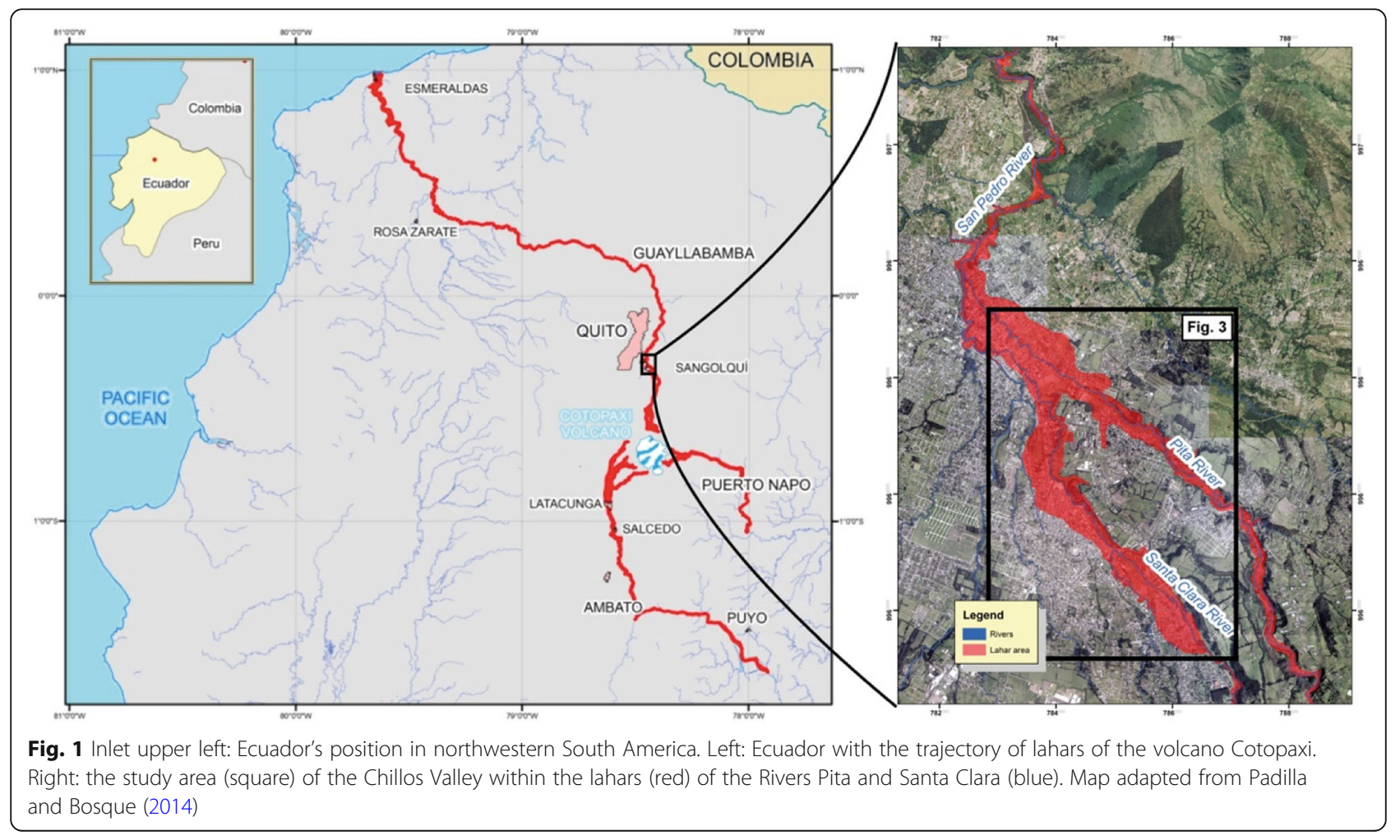


overflow into Santa Clara River (Barberi et al. 1995; Aguilera et al. 2004; Aguilera and Toulkeridis 2005; Cáceres et al. 2004; Padilla and Bosque 2014). The exact overflow point is at the Cabre ravine, which is where the Santa Clara river emerges, as the closest spot between both drainages (Aguilera and Toulkeridis 2005). This current study is the first to relate potential lahar hazard effects on the housing market in Ecuador. A related study of housing market between 2010 and 2014 in the Los Chillos valley (Calderon 2015) determined what characteristics affected house prices during that period of time. Calderon (2015) obtained an average price of 167,862 US dollars per unit, but did not mention whether potential natural hazards could have an effect on the housing market.

\section{Methodology}

The methodology has been divided into an economic and a geographic part. The first part is composed of the hedonic model used, while the second part comprises the GIS tools used for spatial research. The latter is subdivided into six distinctive parts: location variables using GIS tools, the study area, the housing sample, Real Estate information, spatial information database as well as the final OLS regression model used. The combined methodology may be summarized in four different phases, namely planning, the exploratory phase and test, the implementation phase and finally analysis and interpretation (Fig. 2).

\section{Hedonic model}

We have used the hedonic price approach in order to estimate the impact of potential volcanic lahars in residential areas in five parishes of central Ecuador. These parishes are in the lahar hazard area of Cotopaxi volcano and have been historically affected by the lahars triggered by it. The hedonic model is the traditional model developed by Lancaster (1966), Rosen (1974), Quigley and Kain (1970), and Drakopoulos (1991), and it is a function of a combination of structural, neighborhood, and environmental characteristics. The general model may be expressed as:

$$
P=(S, N, E, Z)
$$

Where $P$ is the housing sale price, $S$ refers to structural attributes, $N$ refers to social attributes, $E$ environmental attributes and $Z$ natural hazard attributes. Due to limited information on individual house market prices, mainly because this information is not freely available, and real estate companies are not willing to provide such information, we have used recent house sale prices instead. In addition, because the relationship between price and independent variables may not be linear, we considered a log-semilog function (Gujarati and Porter 2009; Taylor 2008), which may be expressed as:

$$
P_{i}=\beta_{i 1} X_{i}^{\beta_{2}} e^{u_{i}}
$$

where the natural $\log$ of the price of a house $P_{i t h}$ is a function of the $J$ characteristics assumed to influence price, $\hat{\alpha}$ and $\hat{\beta}$ are coefficients to be estimated, and $\varepsilon$ is a normally distributed error term. One of the reasons for using the log-semilog model is to estimate partial elasticity of price housing characteristics (Gujarati and Porter 2009). According to Gujarti and Porter (2009), this elasticity represents the marginal willingness to pay for additional upgrading of housing characteristics.

We have used price as the dependable variable, representing the sale market price. Our independent variables are structural, neighborhood, environmental and natural

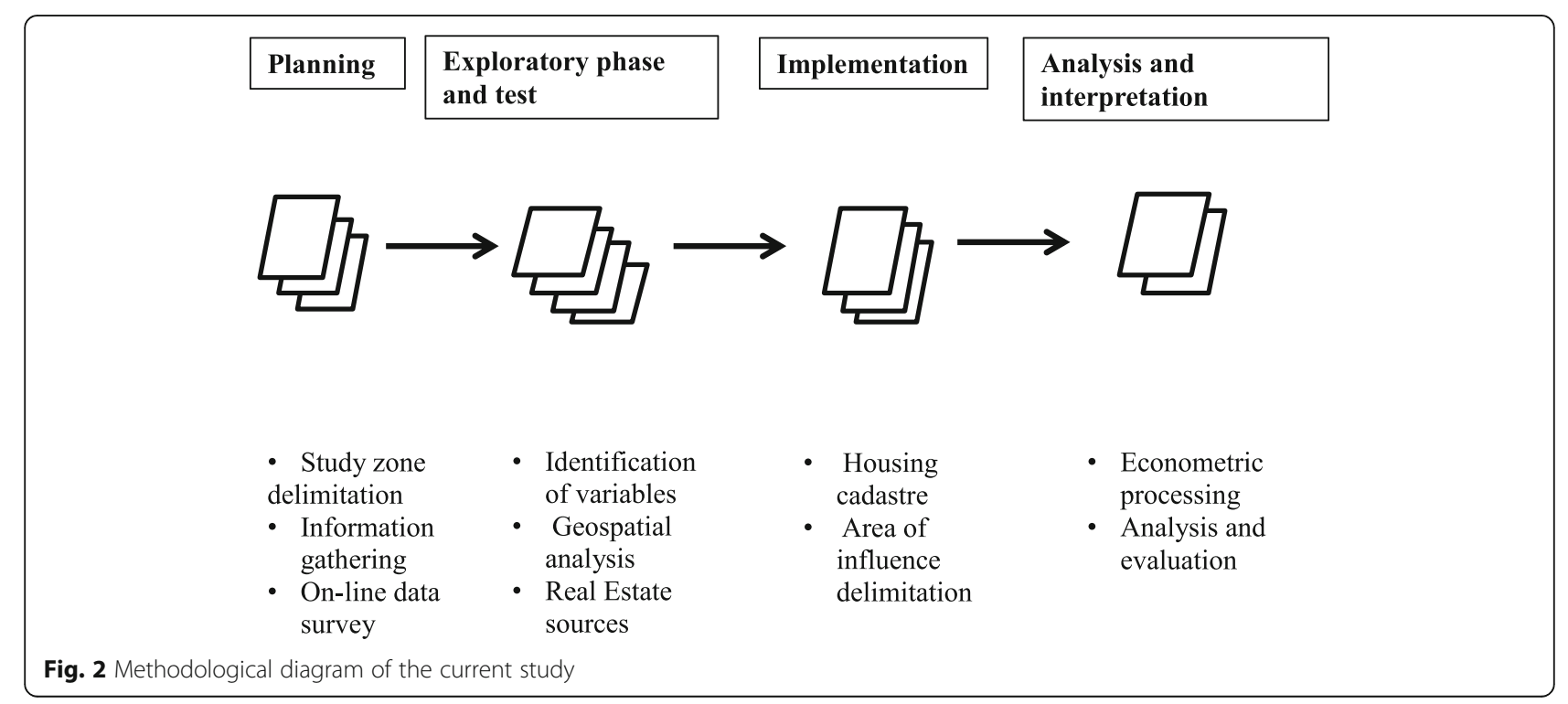


hazards attributes, the latter of which is measured as the distance between selected properties and the Santa Clara River. Structural attributes are nominal variables, meaning the value assigned for each structural characteristic according to house market value. Additionally, five independent dummy variables were settled with available GIS tools, as well as location, to indicate to which parish each house belongs. The specific hedonic pricing model to estimate the effects of potential lahars from Cotopaxi volcano is best expressed with the following equation:

$\ln P_{i}=f\left(\ln A C_{i}, \ln N P_{i}, \ln N D_{i}, \ln N B_{i}, M C_{i}, U E_{i}, C S_{i}, U P C_{i}, A R_{i}, G A_{i}, \ln D, Z A_{i}, P A_{i}\right)$

where:

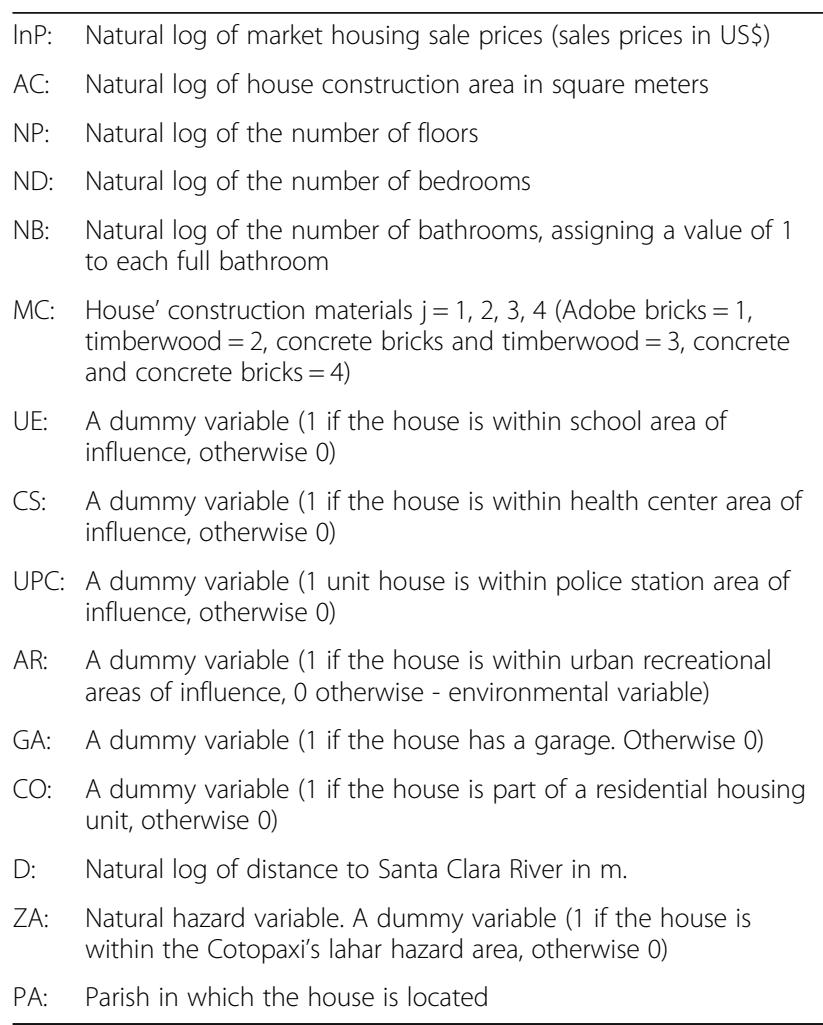

\section{Spatial research}

\section{Location of variables using GIS tools}

Variables of education, health, and police stations were located using GIS tools and GPS data in order to be georeferenced. Regarding recreational parks and houses on sale, we performed a digital survey using a Smartphone application called 'GeoODK collect' ${ }^{\mathrm{tm}}$. This digital survey has been linked to the Formhub platform developed by the Modi Research Group of Columbia University. The digital survey was carried out over 10 days inside the previously delimited study area (Figs. 1, 3 and 4).

\section{Study area}

The study area (Fig. 3) is delimited by an area of $1 \mathrm{~km}$ either side of the Santa Clara River. Based on the Rumiñahui canton and the Metropolitan District of Quito (DMQ) cadastre, 10,012 buildings were located and distributed in five parishes, namely San Rafael (1167), Sangolquí (7425), San Pedro de Taboada (215), Conocoto (533), and Alangasi (762).

\section{Housing sample}

We established a housing sample with Weimer's formula, which is used when the population is finite and a confidence interval is estimated, for the average of the sample (Weimer 2011).

$$
n=\frac{N \sigma^{2} Z^{2}}{(N-1) e^{2}+\sigma^{2} Z^{2}}
$$

where;

$n=$ is sample size.

$N=$ Population size

$\sigma=$ Standard deviation of the population, as it is generally unknown, it takes a constant value of 0.5 .

$Z=$ Confidence value at $95 \%$ which is 1.96 .

$e=$ limit of sample error at $5 \%$.

The housing sample yielded 371 housing units, but we have been able to obtain information only from a percentage of that number. Therefore, a total of 240 housing units were analyzed during the current study, as those units were the only ones on sale during a 6 month period in 2016, when our study was performed.

\section{Real estate information}

In addition to Rumiñahui canton and Quito Metropolitan Distric DMQ cadastre information, we also evaluated information from Real Estate companies, with a variety of useful sites, including Proinmobiliaria (2017), Plusvalia (2017), Provivienda (2017), E-viviendas (2017), Inmofer (2017), Kanda Inmobiliaria (2017), Nuroa (2017), Ecuador Bienes Online (2017), Inmobiliaria Excelencia (2017), Empresas and Servicios Profesionales (2017) and Vive1 (2017).

Housing information from these sites was variable, as such data depend on each Real Estate firm. However, some of the variables were available across all firms such as house price, construction area, number of floors, bedrooms and bathrooms, construction material, existence of a garage, and whether or not the house was part of a residential housing unit. This information was used to estimate the potential effects on house prices of the generation of Cotopaxi's lahars (Table 1). Furthermore, we referenced health and education centers, police stations, recreation areas, as well as zones with respect to the drainages of the lahars, using $\operatorname{ArcGis}^{\text {rm }}$ tools. The zone of 


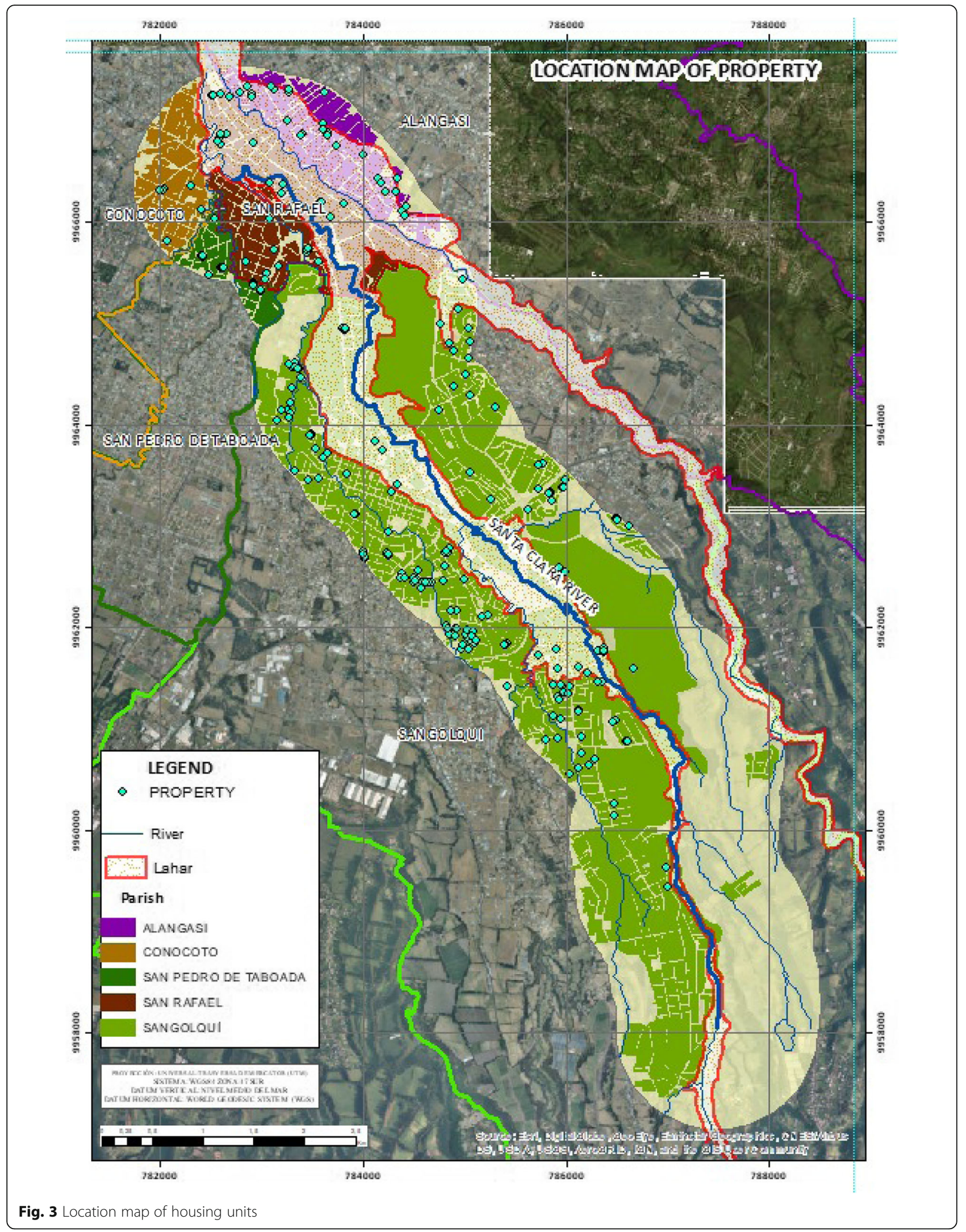




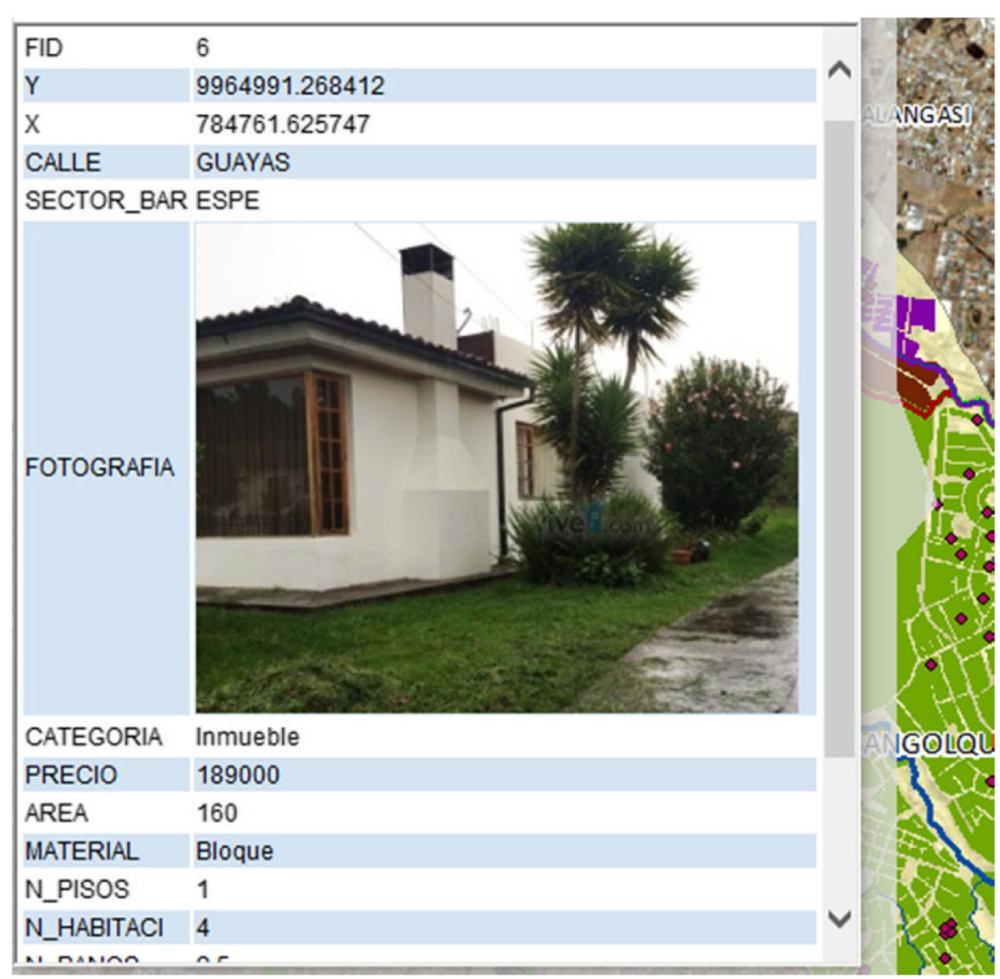

Fig. 4 HTML Popup tool visualization

lahar reach has been spatially located based on recent mapping (Padilla and Bosque 2014).

In order to prevent data wrong interpretation from our study related to social inequality and marginalization where people in disadvantaged and marginalized situations tend to settle on river margins or unsuitable slopes. Bird et al.

Table 1 Descriptive statistics of the used variables

\begin{tabular}{lll}
\hline Variable & $\bar{X}$ & $\boldsymbol{\sigma}$ \\
\hline LogP: & 11.831 & 0.511 \\
LogAC: & 5.122 & 0.544 \\
LogNP: & 0.662 & 0.310 \\
LogND: & 1.179 & 0.303 \\
LogNB: & 1.007 & 0.371 \\
MC: & 3.54 & 0.387 \\
UE: & 0.679 & 0.468 \\
CS: & 0.504 & 0.501 \\
UPC: & 0.296 & 0.457 \\
AR: & 0.387 & 0.387 \\
GA: & 0.975 & 0.156 \\
CO: & 0.800 & 0.401 \\
LogD: & 6.63 & 0.696 \\
ZA: & 0.233 & 0.424 \\
PA & 1.601 & 0.096 \\
\hline
\end{tabular}

(2010) defined as spatial poverty traps. This study takes into consideration value and size of housing units within $100 \mathrm{~m}$ from the river and compares them to the national housing program of Ecuador. This national housing program is set to build units for families living under the poverty line or in inadequate housing. The Ministry of Urban Development and Housing of Ecuador (MIDUVI) housing units have approximately $60 \mathrm{~m}^{2}$ of construction area and a cost of 24,000.00 dollars per house unit (Miduvi 2017). In this study, the value of housing units within 100 $\mathrm{m}$ is much higher than the national housing program.

\section{Spatial information database}

We located and recorded all the data collected using ArcGis $^{\mathrm{Tm}}$ and presented them in a location map in which all 240 sample units were georeferenced (Fig. 3). In addition, we added a field in the ArcView ${ }^{\text {Tw }}$ software to illustrate graphic evidence of each housing unit using an HTML Popup tool (Fig. 4). Afterwards, we determined the distance of each housing sample unit to the Santa Clara River (Fig. 5). Furthermore, we also used ArcGis ${ }^{\mathrm{ma}}$ to set an area of influence of neighborhood attribute variables. Local and national regulations establish the appropriate distance for services such as hospitals and other health services, education such as schools and high schools, as well as police headquarters related to the size of the population (Senplades 2014). Based on 


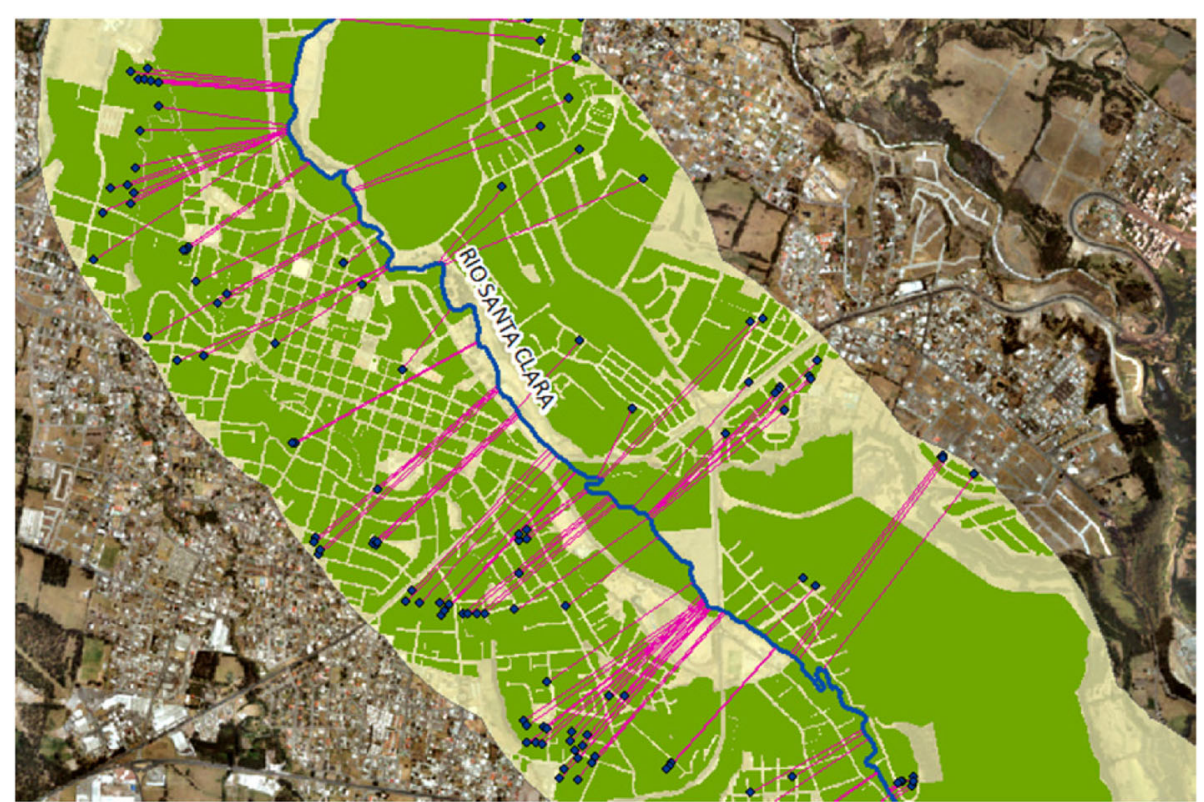

Fig. 5 Distances of real estate towards the Santa Clara river

these regulations, we set the area of influence that helped to define our CS, UE and UPC variables.

\section{Final OLS regression model}

Finally, when our probabilistic model had been settled, it demonstrated the relationship between our dependent variable $(\ln \mathrm{P})$ and the semilog independent variables. The following equation of our regression model has been expressed as follows:

$$
\begin{aligned}
\ln P= & \beta_{0}+\beta_{1} \ln \mathrm{AC}+\beta_{2} \mathrm{MC}+\beta_{3} \operatorname{lnNP} \\
& +\beta_{4} \operatorname{lnND}+\beta_{5} \ln \mathrm{NB}+\beta_{6} \mathrm{GA}+\beta_{7} \mathrm{CO} \\
& +\beta_{8} \mathrm{AR}+\beta_{9} \mathrm{CS}+\beta_{10} \mathrm{UPC}+\beta_{11} \mathrm{UE} \\
& +\beta_{12} \ln \mathrm{D}+\beta_{13} \mathrm{ZA}+\beta_{14} \mathrm{PA}_{14}+\varepsilon
\end{aligned}
$$

Where $\beta_{0}$ is the variable that expresses the intercept generated on axis $\mathrm{Y}(\mathrm{P})$.

We performed the regression and determined the adjusted $R^{2}$ coefficient in order to establish the relationship between each independent variable with our dependent variable (Vivanco 2005). As some inconsistencies appeared in this first model, we did not take into consideration some of the variables due to evident collinearity. A Dublin Watson test was conducted in order to correct any autocorrelation problem. Therefore, the final hedonic price log-log model was expressed as follows:

$$
\begin{aligned}
\ln P= & \alpha_{0}+\alpha_{1} \ln A C+\alpha_{2} N P+\alpha_{3} N B+\alpha \beta_{4} \ln D i s \\
& +\epsilon
\end{aligned}
$$

where,
InP: Natural log of market housing sale prices (housing sale prices in US\$)

InAC: Natural log of house construction area (construction area in square meters)

InNP: Natural log of the number of floors (number of floors in units)

InNB: Natural log of the number of bathrooms, (assigning value of 1 to each full bathroom - units)

InD Natural log of distance to Santa Clara River (distance in $\mathrm{m}$ ). Natural hazard variable

\section{Results and discussion}

Initially, 13 independent variables were considered in the hedonic price model (Table 1). This initial analysis yielded a 0.817 adjusted $R^{2}$ (Table 2). The results indicate that only three variables were significant at $99 \%$ : housing area (AR), number of floors per housing unit (NP) and environmental amenity variable (AR), reflecting a recreational park (Table 2). The rest of the impendent variables lacked significance, including distance to Santa Clara River, which was our natural hazard risk variable. The variable construction material $\mathrm{MC}$ also lacked significance, as almost all houses were built of concrete and concrete bricks. Therefore, this variable clearly did not vary. Similarly, the variable number of bedrooms NB was not significant. We attribute the latter to a lack of variability in the housing sample, as the vast majority of units had three bedrooms, while very few houses had more or less three bedrooms and none of the houses had only one bedroom. 
Table 2 Results of log-semilog model

\begin{tabular}{ll}
\hline Variable & Log-Log Model \\
\hline Dependent & Log (pm) \\
Constant & $8.510(24.448)^{c}$ \\
LnAC & $0.730(13.656)^{c}$ \\
MC & $-0.013(-0.311)$ \\
LnNP (units) & $-0.113^{\mathrm{a}}(-1.725)$ \\
LnNH (units) & $0.007(0.062)$ \\
LnNB (units) & $0.132(1.488)$ \\
GA & $-0.108(-1.040)$ \\
CO & $0.003(0.066)$ \\
AR & $-0.214(-4.665)^{c}$ \\
CS & $0.043(1.317)$ \\
UPC & $-0.0004(-0.009)$ \\
UE & $0.03318(0.416)$ \\
LnD (m) & $-0.004(-0.156)$ \\
ZA & $-0.055(-1.178)$ \\
PA & $-0.187(-1.099)$ \\
$R^{2}$ Adjusted & 0.817 \\
Durbin-Watson & 1.882 \\
F-Stat & $77.249461^{c}$ \\
\hline Stisticsta & \\
\hline
\end{tabular}

Statistics $t$ are in parentheses. ${ }^{a}$ Exceeds $90 \%$ confidence level $(t>|1.28|$; ${ }^{b}$ Exceeds $95 \%$ confidence level ( $t>|1.96| ;{ }^{C}$ Exceeds $99 \%$ confidence level $(\mathrm{t}>|2.58|$

Nonetheless, we needed to eliminate some of the variables due to the evident existing collinearity between them. We ran a Durbin-Watson test in order to correct any correlation. Within the final regression model, the Durbin-Watson test yielded a value of about 1.882 . Moreover, the variable recreational park $A R$ bends the variable distance $D$, which measures the natural hazard risk, i.e., the distance between housing units and the Santa Clara River, the natural path of a potential Cotopaxi lahar. The Santa Clara River is a lineal recreation park recognized by the local government of the Rumiñahui canton. In order to receive the protection status of "lineal recreation park", the recreational park of Santa Clara River needed to meet some environmental standards including being free or close to free of contamination. The water quality of Santa Clara River has high water quality (Guzmán Salazar 2011). As an environmental amenity, AR was statistically significant with a $\beta_{8}$ coefficient value of $-0,214$ and 0.000 of significance, while for the distance $\mathrm{D}$ we yielded a $\beta_{12}$ coefficient of 0.004 (Table 2), lacking statistical significance. Regarding spatial poverty traps, we encountered only eleven housing units located within $100 \mathrm{~m}$ from Santa Clara River. The average construction areas of these units was $178.64 \mathrm{~m}^{2}$ and the housing value reached over 115,000 US dollars per unit. Our sample units close to Santa
Clara River did not fit with the national housing program housing standards; therefore, our units were not suitable to be considered as part of spatial poverty trap problem.

In order to determine whether an awareness of the Santa Clara River as a lahar hazard zone exists, and how it would influence housing values, we did not consider the variable $A R$ in the final regression, leading to interesting results. The new hedonic price model has an adjusted $R^{2}$ of 0.791 (Table 3). All variables used in the final regression log-log model were statistically significant. The variable $D$ improves considerably, with the $\beta_{4}$ coefficient value of 0.043 and a significance of 0.057 (Table 3).

The results demonstrate that a natural hazard such as volcano's lahar has a significant negative effect on housing values. In the particular case of Cotopaxi's lahars, house prices increase by $4.3 \%$ in value with each $1 \%$ increase in distance away from Santa Clara River (Table 5). Certainly, it does not appear to be a huge value difference at first glance, but residents of the studied valley affected by the Cotopaxi volcano have just recently become aware of any potential economic losses and may be taking this into consideration when buying a property. Yet, the results support our initial assumption that a natural hazard significantly affects property value. Sixty four houses of the sample are at direct risk impact from Cotopaxi's lahars.

As expected, the number of bathrooms has a positive impact on house prices and was statistically significant as well (Table 3). An interesting result is the number of floors, which we expected to have a positive effect on house prices, but the results suggest otherwise.

The reasons for this unexpected result is unknown, but it is possible that a local government ordinance may have played a significant role. This ordinance limits the number of floors for residential and commercial buildings. It may be also possible that a limited area for

Table 3 Results of log-log model

\begin{tabular}{ll}
\hline Variable & Log-Log Model \\
\hline Dependent & Log $(\mathrm{pm})$ \\
Constant & $7.770(33.085)^{c}$ \\
LnA (m $\left.{ }^{2}\right)$ & $0.724(15.070)^{c}$ \\
LnN_P (units) & $-0.208(-3.581)^{c}$ \\
LnN_B (units) & $0.218(2.824)^{c}$ \\
LnD (m) & $0.043(1.910)^{\mathrm{a}}$ \\
$\mathrm{R}^{2}$ & 0.791 \\
Durbin-Watson & 1.694 \\
F-Stat & $227.26^{c}$ \\
\hline
\end{tabular}

Statistics $t$ are in parentheses. ${ }^{a}$ Exceeds $90 \%$ confidence level $(t>|1.28|$; ${ }^{\mathrm{b}}$ Exceeds $95 \%$ confidence level ( $\mathrm{t}>|1.96| ;{ }^{\mathrm{C}}$ Exceeds $99 \%$ confidence level $(\mathrm{t}>|2.58|$ 
land parcels induces local residents to build up to four floors in accordance with the Rumiñahui canton ordinance, but within an area no greater than $130 \mathrm{~m}^{2}$. The resulting values of these houses are between 80 and 120 thousand USD.

Our hedonic price model is summarized in the following equation:

$$
\begin{aligned}
\ln P= & 7.77+0.724 * \ln A C-0.209 * \ln N P \\
& +0.218 * \ln N B+0.043 * \ln D
\end{aligned}
$$

Finally, we note that our study area is not exclusively a residential area, rather there are also local and national government agencies as well as commercial buildings such as malls and restaurants. However, we did not consider these buildings in our hedonic price model.

\section{Conclusions}

The Hedonic Regression Model allowed us to estimate the effect of potential lahars from the Cotopaxi volcano on housing. As a tool, the hedonic price model enabled us to determine the correlation between house characteristics and the sale price. The results illustrate that distance $D$ has a positive $\beta$ coefficient value with price, meaning that the price of a residential house property located within Cotopaxi's lahar hazard area is significantly lower than that of other residential properties located outside of the area of the lahars' influence. We determined that the price of a residential unit increases by $4.3 \%$ for each $1 \%$ in distance moving away from the Santa Clara River. The results are significant because, with an average housing price unit of 159,239 US\$, the lost 6863 US\$ represents a significant drop in property value. This average housing price 159,000 is $5.1 \%$ lower than the price reported by Calderon (2015) in his study.

We found 64 houses from our sample at direct risk of impact from potential lahars from Cotopaxi, and we suggest local government should consider expanding the current study in order to determine how many more properties would be directly affected. There are some limitations to our analysis since we did not compare the natural hazards insurance cost. This has been partly because there is limited information about that kind of insurance premium from the area of study. There is also an extremely limited market of natural hazards insurance programs in the residential area of Sangolquí. Therefore, we expect that any price differential, as revealed in our study, would be greater than the cost of lahar insurance premiums. For this research, we did not consider a time series study due to restricted information regarding the housing market in the area of study. Based on the information from Real Estate firms' web information of sales during 6 months in 2016, our results are site-specific. Therefore, our data analysis may not be suited to any generalization required for policy making. Nevertheless, the results highlight the need for other studies that focus on policy mitigation.

\section{Abbreviations \\ DMQ: Metropolitan District of Quito; GIS: Geographic information systems; GPS: Global positioning system; HTML: HyperText markup language; MIDUVI: Ministry of urban development and housing; OLS: Ordinary least squared; TM: Trademark; USA: The United States of America; USD: United States Dollars; VEl: Volcanic explosivity index}

\section{Acknowledgments}

Authors would like to express their gratitude with Dr. Oswaldo Padilla, for allowing us to use his Cotopaxi lahars model and helping us to locate it in our area of study. We also would like to acknowledge Dr. Elizabeth Winkler for assisting with the final English version of this manuscript.

\section{Authors' contributions}

Contribution of each author is as follows: B.Sc. Richard Caleb EchegarayAveiga designed the spatial model and potential effects on housing gathered real estate information. Dr. Fabián Rodríguez-Espinosa focused on economic modeling and analysis. Dr. Theofilos Toulkeridis worked on potential damage by Cotopaxi volcano's lahar. B.Sc. Richard Damian Echegaray-Aveiga gathered real estate information and tabulated all data. The author(s) read and approved the final manuscript

\section{Authors' information}

Information about authors was included in the ADD/Edit Authors Section of the journal submissions format.

\section{Funding}

There was no funding for this research, and it was declared in the Funding Information Section of the journal submissions format.

\section{Availability of data and materials}

The data were gathered from Real Estate business companies, which are included in the paper's Reference List.

\section{Ethics approval and consent to participate}

Not applicable. The present study was designed using public information and data, as a result, it did not require consent to participate. Additionally, the econometric model has no ethical implications and did not affect any person that might require ethics approval.

\section{Consent for publication}

The main goal of authors of this research was, and still is, to get published as it is clearly included in "cover letter" where authors are declaring their consent.

\section{Competing interests}

We ensure, that our manuscript has NOT been submitted simultaneously for publication anywhere else, containing original data and a paper not presented previously at any congress as it was stated in the author's "cover letter". We do not have any material (figures, images or tables) included in the manuscript that may require to obtain permission to reproduce copyrighted material from other sources, and there is no conflict of interest with any party.

Received: 23 May 2019 Accepted: 11 March 2020

Published online: 14 April 2020

\section{References}

Aguilera E, Pareschi MT, Rosi M, Zanchetta G (2004) Risk from lahars in the northern valleys of Cotopaxi volcano (Ecuador). Nat Hazards 33(2):161-189. https://doi.org/10.1023/B:NHAZ.0000037037.03155.23 
Aguilera E, Toulkeridis T (2005) El Volcán Cotopaxi - Una amenaza que se acecha. COSUDE, CGVG-USFQ, ESPE, FOES, Quito

Barberi F, Coltelli M, Frullani A, Rosi M, Almeida E (1995) Chronology and dispersal characteristics of recently (last 5000 years) erupted tephra of Cotopaxi (Ecuador): implications for long-term eruptive forecasting. J Volcanol Geotherm Res 69(3):217-239. https://doi.org/10.1016/03770273(95)00017-8

Bernknopf R, Brookshire D, Thayer M (1990) Earthquake and volcano Hazard notices: an economic evaluation of changes in risk perception. J Environ Econ Manag 18:35-49. https://doi.org/10.1016/0095-0696(90)90050-9

Beron K, Murdoch J, Thayer M, Vijverberg W (1997) An analysis of the housing market before and after the 1989 Loma Prieta earthquake. Land Econ 73: 101-113. https://doi.org/10.2307/3147080

Bin O, Brown Kruse J, Landry CE (2008) Flood hazards, insurance rates, and amenities: evidence from the coastal housing market. Journal of Risk and Insurance 71(1):63-82. https://doi.org/10.1111/j.1539-6975.2007.00248.x

Bin O, Polasky S (2004) Effects of flood hazards on property values: evidence before and after hurricane Floyd. Land Econ 80(4):490-500. https://doi.org/10. 2307/3655805

Bird K, Higgins K, Harris D (2010) Spatial poverty traps: an overview, ODI working paper 321, CPRC working paper 161. Overseas Development Institute, chronic poverty research center, London, $\mathrm{p} 12$

Brookshire DS, Thayer MA, Tschirhart J, Schulze WD (1985) A test of the expected utility model: evidence from earthquake risks. J Polit Econ 93(2):369-389. https://doi.org/10.1086/261304

Cáceres B, Ramírez J, Francou B, Eissen JP, Taupin JD, Jordan E, Ungerechts L, Maisincho L, Barba D, Cadier E, Bucher R, Peñafiel A, Samaniego P, Mothes P (2004) Determinación del volumen del casquete de hielo del volcán Cotopaxi. Report INAMHI. IRD, IG-EPN, INGEOMINAS, Quito

Calderon RD (2015) Diagnóstico de las variables de incidencia en la fijación de preciosde las casas en el sector del Valle de los Chillos 2010-2014. Tesis de Grado previo a la obtención del Grado de Magister en Gerencia EmpresarialFacultad de Ciencias Administrativas Escuela Politécnica Nacional, Quito https://bibdigital.epn.edu.ec/bitstream/15000/11374/1/CD-6454.pdf

De Koning K, Filatova T, Bin O (2016) Improved methods for predicting property prices in Hazard prone dynamic markets. Environ Resour Econ 136:1-13. https://doi.org/10.1007/s10640-016-0076-5

Donovan GH, Champ PA, Butry DT (2007) Wildfire risk and housing prices: a case study from Colorado Springs. Land Econ 83(2):217-233

Drakopoulos S (1991). Values and Economic Theory: The Case of Hedonism. Library Aldershot Avebury, U.K.; Brookfield, Vt. and Sydney. 235 pp

Ecuador Bienes Online (2017) Casas en Ruminahui de Venta http://ecuador. bienesonline.com/casas-venta-ruminahui_t1011117.php [Accessed 03 June 2017]

Egbenta IR, Udo GO, Otegbulu AC (2015) Using hedonic Price model to estimate effects of flood on real property value in Ñokoja Nigeria. Ethiopian Journal of Environmental Studies \& Management 8(5):507-516. https://doi.org/10.4314/ ejesm.v8i5.4 AJOL African Journals Online

Empresas \& Servicios Profesionales (2017) Busco casita. Localidad Valle de los Chillos http://www.buscocasita.com/ecuador/buscar-inmuebles.php?tn=En+ Venta\&ta=Casa\&pr $1=\& p r 2=\& p=19 \& c=131 \&$ propiedades=Buscar $[$ Accessed 03 June 2017]

Epple D (1987) Hedonic prices and implicit markets: estimating demand and supply functions for differentiated products. J Polit Econ 95(1):59-80. https:// doi.org/10.1086/261441

e-viviendas (2017) Inmuebles casas http://www.e-viviendas.com/category.php?id category $=3$ [Accessed 03 June 2017]

Feenstra R (1995) Exact hedonic Price indexes. Rev Econ Stat 77(4):634-653. https://doi.org/10.3386/w5061

Garrison JM, Davidson JP, Hall M, Mothes P (2011) Geochemistry and petrology of the most recent deposits from Cotopaxi volcano, northern volcanic zone, Ecuador. J Petrol 52(9):1641-1678

Gujarati DN, Porter DC (2009) Basic econometrics fifth edition. MacGraw-Hill/Irvin, Inc, New York, p 280

Guzmán Salazar RX (2011) Diagnóstico de la calidad del agua del Rio Santa Clara en el sector del barrio Selva Alegre-Cantón Rumiñahui. Doctoral dissertation, Universidad Internacional SEK, Quito, p 97

Hallstrom D, Smith VK (2005) Market responses to hurricanes. J Environ Econ Manag 50:541-561. https://doi.org/10.1016/j.jeem.2005.05.002

Hulten CR (2003) Price hedonics: a critical review. Federal Reserve Bank of new York Economic Policy Review, Vol. 9, no. 3. SSRN, New York https://ssrn.com/ abstract $=788904$
Inmobiliaria Excelencia (2017) Casa Ruminahui http://www.inmobiliariaexcelencia. com/index.php [Accessed 03 June 2017]

Inmobiliaria K (2017) Ciudad Sangolqui Obtenido de http://www. kandainmobiliaria.com/main-buscar.htm?ciudad=562897\&zona=0\&tipo inmueble $=0 \&$ tipo_negocio $=0 \&$ precio $=0 \&$ estado $=0 \&$ num $=12$ [Accessed 03 June 2017]

Inmofer (2017) Compra casas Obtenido de http://inmofer.net/index.php/compra/ casas [Accessed 03 June 2017]

Kiel K, Matheson V (2015) The effect of natural disasters on housing Price: an examination of the Fourmile canyon fire, Holy cross working paper series, paper no. 15-03. College of hoy Cross, Department of Economics, Worcester https://crossworks.holycross.edu/econ_working_papers/157

Kriesel W, Randall A, Lichtkoppler F (1993) Estimating the benefits of shore erosion protection in Ohio's Lake Erie housing market. Water Resources Journal 29(4):795-801. https://doi.org/10.1029/92WR02539

La Condamine CM (1751) Diario del Viaje al Ecuador, republ. In 1986. Publitécnica, Quito, p 221

Lancaster KJ (1966) A new approach to consumer theory. J Polit Econ 74(2):132157. https://doi.org/10.1086/259131

Landry CE, Keeler AG, Kriesel W (2003) An economic evaluation of beach erosion management alternatives. Mar Resour Econ 18:105-127. https://doi.org/10. 1086/mre.18.2.42629388

MacDonald D, White H, Taube P, Huth W (1990) Flood Hazard pricing and insurance premium differentials: evidence from the housing market. Journal of Risk and Insurance 57:654-663. https://doi.org/10.2307/252950

MacDonald DN, Murdoch JC, White HL (1987) Uncertain hazards, insurance, and consumer choice: evidence from housing markets. Land Econ 63(4):361-371 https:/www.jstor.org/stable/3146293

Miduvi (2017) Programa Nacional de Vivienda: Proyecto 2017. Ministerio de Desarrollo Urbano y Vivienda, Subsecretaría de Vivienda, Dirección de Gestión y Ejecución de Vivienda, Quito, p 18 https://www.habitatyvivienda. gob.ec/wp-content/uploads/downloads/2018/01/Programa-Nacional-deVivienda-Social.pdf

Miller CD, Mullineaux DR, Hall ML (1978) Reconnaissance map of potential volcanic hazards from Cotopaxi volcano, Ecuador. Report from USGS, Department of Interior, United States Geological Survey, Arlington

Modi Research Group (2012) GitHub - SEL-Columbia/formhub: Mobile data collection made easy. Quadracci Sustainable Engineering Lab, The Earth Institute, Columbia University, New York http://www.github.com/modilabs/ formhub [Accessed 03 June 2017]

Mothes PA (1992) Lahars of Cotopaxi volcano, Ecuador: hazard and risk evaluation. In: Geohazards. Springer, Dordrecht, pp 53-63

Murdoch JC, Singh H, Thayer M (1993) The impact of natural hazards on housing values: the Loma Prieta earthquake. Real Estate Econ 21(2):167-184. https:// doi.org/10.1111/1540-6229.00606

Nuroa (2017) Casa Valle de los chillos https://www.nuroa.com.ec/venta/casa-vallede-los-chillos [Accessed 03 June 2017]

Padilla O, Bosque J (2014) Determinación de Puntos de Evacuación vertical y horizontal en Caso de Erupción del Volcán Cotopaxi en el Valle de los Chillos, Sangolquí, Ecuador. Revista Geoespacial 11:67-79

Pistolesi M (2008) Historical analysis and stratigraphy of the post-XII century pyroclastic activity at Cotopaxi volcano, Ecuador: implication for lahar hazard assessment. Plinius 34:131-138

Pistolesi M, Cioni R, Rosi M, Aguilera E (2014) Lahar hazard assessment in the southern drainage system of Cotopaxi volcano, Ecuador: results from multiscale lahar simulations. Geomorphology 207:51-63. https://doi.org/10. 1016/j.geomorph.2013.10.026

Pistolesi M, Cioni R, Rosi M, Cashman KV, Rossotti A, Aguilera E (2013) Evidence for lahar-triggering mechanisms in complex stratigraphic sequences: the post-twelfth century eruptive activity of Cotopaxi volcano, Ecuador. Bull Volcanol 75(3):1-18. https://doi.org/10.1007/s00445013-0698-1

Plusvalia (2017) Casas en Venta Sangolqui http://www.plusvalia.com/casas-enventa-en-sangolqui.html [Accessed 03 June 2017]

Proinmobiliaria (2017) Casas los chillos http://proinmobiliaria.com/es/Casas/Los+ Chillos/5-4/0-1--g-p-0/ [Accessed 03 June 2017]

Provivienda (2017) Inmuebles disponibles http://provivienda.com.ec/inmueblesdisponibles/realties?option=com_jux_real_estate\&view=realties\&list_style= grid\&ltemid=696\&agent_id=\&cat_id=35\&type_id=0\&price_slider_lower=

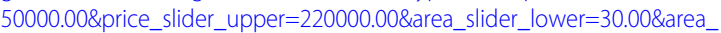
slider_upper=4 [Accessed 03 June 2017] 
Pryce G, Chen Y, Galster G (2011) The impact of floods on house prices: an imperfect information approach with myopia and amnesia. Hous Stud 26(2): 259-279. https://doi.org/10.1080/02673037.2011.542086

Quigley JM, Kain JF (1970) Measuring the value of housing quality. Journal of the American Statistical Society 65(330):532-548 www.tandfonline.com/doi/abs/1 $0.1080 / 01621459.1970 .10481102$

Rosen S (1974) Hedonic prices and implicit markets: product differentiation in pure competition. J Polit Econ 82:34-55. https://doi.org/10.1086/260169

Rodríguez F, Toulkeridis T, Sandoval W, Padilla O, Mato F (2017) Economic risk assessment of Cotopaxi volcano, Ecuador, in a case of future lahar emplacement. Nat Hazards 85:605-618. https://doi.org/10.1007/s11069-0162589-1

Rossi AJ (2014) Wildfire risk and the residential housing market: a spatial hedonic analysis. CUREJ: College Undergraduate Research Electronic Journal University of Pennsylvania. https://repository.upenn.edu/curej/178

Samarasinghe O, Sharp B (2010) Flood prone risk and amenity values: a spatial hedonic analysis. Aust J Agric Resour Econ 54:457-475. https://doi.org/10. $1111 / j .1467-8489.2009 .00483 . x$

Senplades (2014) Distribución espacial referencial de los establecimientos prestadores de servicios públicos. Senplades, 1ra Edicion. Secretaria Nacional de Planificación y Desarrollo, Quito, p 80

Sodiro L (1877) Relación sobre la Erupción del Cotopaxi Acaecida el Día 26 de Junio, de 1877. Imprenta Nacional, Quito, p 40

Taylor LO (2008) Theoretical foundations and empirical developments in hedonic modeling. In: Baranzini A, Ramirez J, Schaerer C, Thalmann P (eds) Hedonic methods in housing markets: pricing environmental amenities and segregation. Springer, New York, pp 15-38. https://doi.org/10.1007/978-0387-76815-1

Timar L, Grimes A, Fabling R (2014) That sinking feeling: the changing Price of disaster risk following and earthquake, Motu working paper 14-13. Motu economic and public policy research, Wellington. https://doi.org/10.2139/ ssin.2523204

Toulkeridis T (2013) Volcanes Activos Ecuador, Quito. https://doi.org/10.1016/j. jvolgeores.2007.10.008

Toulkeridis T, Arroyo CR, Cruz D'Howitt M, Debut A, Vaca AV, Cumbal L, Mato F, Aguilera E (2015) Evaluation of the initial stage of the reactivated Cotopaxi volcano - analysis of the first ejected fine-grained material. Nat Hazards Earth Syst Sci 3(11):6947-6976. https://doi.org/10.5194/nhessd-3-6947-2015

Toulkeridis T, Jacome A, Mato F (2018) Ethics, policy, and risk assessment of the Cotopaxi volcanic crisis in Ecuador-vulnerable society versus unprepared volcanic monitoring staff and authorities. In: Geoethics in Latin America. Springer, Cham, pp 153-170

Toulkeridis T, Zach I (2017) Wind directions of volcanic ash-charged clouds in Ecuador-implications for the public and flight safety. Geomatics, Natural Hazards, and Risk 8(2):242-256

Triplett J (1983) Concepts of quality in input and output Price measures: a resolution of the user value-resource cost debate. In: Foss MF (ed) The U.S. National Income and product accounts: selected topics. Studies in income and wealth 47. University of Chicago Press and National Bureau of economic research, Chicago, pp 296-311 http://www.nber.org/chapters/c7787

Troy A, Romm J (2004) Assessing the price effects of flood hazards disclosure under the California natural hazard disclosure law (AB 1195). J Environ Plan Manag 47(1):137-162. https://doi.org/10.1080/0964056042000189844

Vaca AV, Arroyo CR, Debut A, Toulkeridis T, Cumbal L, Mato F et al (2016) Characterization of fine-grained material ejected by the Cotopaxi volcano employing X-ray diffraction and electron diffraction scattering techniques. Biol Med (Aligarh) 8(280):2

Vivanco M (2005) Muestreo estadístico. Diseño y aplicaciones. Editorial Universitaria, Santiago de Chile

Vive1 (2017) Venta sangolqui Obtenido de http://ecuador.vive1.com/buscar/ venta/-/-/-/-/-\#/ [Accessed 03 June 2017]

Weimer RC (2011) Estadística. Grupo editorial Patria, México

Whymper $E$ (1892) Travels amongst the great Andes of the equator. Peregrine Smith Books, Salt Lake City, p 456

Wolf T (1878) Memoria sobre el Cotopaxi y su ultimaerupcion acaecida el 26 de junio de 1877. Imprenta del Comercio, Guayaquil, p 64

\section{Publisher's Note}

Springer Nature remains neutral with regard to jurisdictional claims in published maps and institutional affiliations.

\section{Ready to submit your research? Choose BMC and benefit from}

- fast, convenient online submission

- thorough peer review by experienced researchers in your field

- rapid publication on acceptance

- support for research data, including large and complex data types

- gold Open Access which fosters wider collaboration and increased citations

- maximum visibility for your research: over $100 \mathrm{M}$ website views per year

At BMC, research is always in progress.

Learn more biomedcentral.com/submissions 